\title{
ANALISIS DAN PERANCANGAN E-GOVERMENT DALAM TRANSPARANSI SISTEM PEMERINTAHAN DESA (Studi Kasus : Desa Tenjo Layar dan Desa Tanjung Sari Majalengka)
}

\author{
Dede Abdurahman ${ }^{1}$, Tri Ferga Prasetyo ${ }^{2}$ \\ 1,2) Teknik Informatika, Fakultas Teknik, Universitas Majalengka \\ dzildan@gmail.com
}

\begin{abstract}
Fast, accurate and accurate information needs to be one of the basic development of information and communication technology. The type of service and support in the field of information and communication technology (ICT) on governance is a strategic part in ensuring the improvement of service quality and support in applying e-Government to Village Governance.

Village Governance and clean, transparent public services are challenges that the village government must answer in performing its functions as a public servant. With infrastructure facilities in the field of ICT already available in the village and administrative issues that need to get serious attention, thereby encouraging Researchers to utilize existing ICT infrastructure by analyzing and designing e-government applications that suit the needs of the village and in accordance with the Village Law article 4 letter $\mathrm{f}$ which reads to improve public services for the villagers to accelerate the realization of general welfare, and article 7 paragraph 3 letter $\mathrm{c}$ which reads accelerate the improvement of public service quality.

Based on the above study, the public service and e-Government support provided by the Village Government through the application of information and communication technology is the focus of the researcher in this research, with the aim of improving the service to the village community and improving the performance of village government apparatus, for the analysis and design of e- government Researchers are based on policies and National Strategy e-Government development is done in several stages namely, Level 1 - Preparation, which is making the website as a medium of information and communication at each institution. Level 2 - Maturation, which is the creation of an interactive public information web portal. Level 3 - Stabilization, which is the creation of a web portal that is a public service electronic transaction. Level 4 - Utilization, ie application creation for Government to Government (G2G), Government to Business (G2B), Government to Consumers / community (G2C) services.

The method of this study using the usual research methods used in the development of system life cycle system development (SDLC). The main stages may consist of system planning stages, system analysis, system design, system selection, system implementation and system maintenance.

As for the method of data collection using the method of observation, interview, and literature study. The final step in this application development process is system testing. The system tested using 2 ways, namely: Blackbox test and Alpha test. Blackbox test, performed by system programmers while Alpha test performed simultaneously with user training.
\end{abstract}

Keyword : Service, ICT, e-Government, SDLC

\section{PENDAHULUAN}

Penerapan Teknologi Informasi dan Komunikasi (TIK) saat ini, menjadi isu yang penting di semua institusi/lembaga baik perusahaan swasta, BUMD dan BUMN, lembaga pendidikan dan pemerintahan. Penerapan Teknologi Informasi dan Komunikasi (TIK) di pemerintahan khususnya Pemerintahan Desa diantaranya untuk kepentingan pelayanan publik seperti administrasi kependudukan, dan administrasi Pembangunan Desa. Pelayanan administrasi desa yang menggunakan TIK merupakan suatu terobosan dalam rangka peningkatan kepuasan masyarakat desa akan kinerja pemerintah desa sekaligus optimalisasi di bidang teknologi informasi dan komunikasi yang mana dengan pemanfaatan teknologi ini masyarakat dapat dilayani kapanpun dan dimanapun.
Sejak tahun 2007 sampai dengan tahun 2009 Pemerintah telah mencanangkan pengembangan infrastruktur telekomunikasi dan internet ke seluruh wilayah Indonesia dalam skema Program USO (Universal Service Obligation).

Kebijakan ini dituangkan dalam Peraturan Menteri Komunikasi dan Informatika nomor 11/PER/M.KOMINFO/04/2007 dan 48/PER/M. KOMINFO/11/2009[1, 2].

Dari Berita Kominfo diperoleh informasi bahwa dengan flagshipnya Desa Berdering, sampai Februari 2010 telah terpasang 25.176 desa berdering dan 100 desa pinter yang sudah memiliki akses Internet. Visi Pemerintah untuk mewujudkan 10 ribu Desa Pinter di tahun 2014, telah dijalankan dengan memulai program PLIK (Pusat Layanan Jasa Akses Internet Kecamatan) di 5.748 ibukota kecamatan mulai tahun 2010. Berdasarkan informasi diatas 
maka penerapan teknologi informasi dan komunikasi (TIK) di pemerintahan desa pada bidang e-goverment dapat di implementasikan dengan baik, baik sistem e-goverment pada sektor G2G (government-to-government), G2B (government-tobusiness), maupun G2C (government-to-citizen).

Pada saat ini, perangkat perundangan mengenai e-goverment di Indonesia sudah cukup lengkap, walaupun dibandingkan dengan negaranegara maju relative terlambat. Dukungan pemerintah mengenai pentingnya penerapan egoverment baru mulai tampak pada awal tahun 1990-an walaupun di sektor swasta sudah banyak pelaku bisnis besar yang menggunakan teknologi dengan konsep e-commerce, e-banking atau telemarketing. Menyadari pentingnya penerapan konsep e-goverment, pemerintah menerbitkan Inpres No.3 tahun 2003 mengenai Strategi Pengembangan e-government. Berdasarkan Undang-Undang Desa pasal 4 huruf f yang berbunyi meningkatkan pelayanan publik bagi warga masyarakat Desa guna mempercepat perwujudan kesejahteraan umum, dan pasal 7 ayat 3 huruf c yang berbunyi mempercepat peningkatan kualitas pelayanan publik. Strategi pokok yang diambil oleh pemerintah baik pusat maupun daerah dalam mencapai e-goverment adalah sebagai berikut: (1) Pengembangan sistem pelayanan yang andal dan terpercaya serta terjangkau oleh masyarakat luas. (2) Penataan sistem manajemen dan proses kerja pemerintah pusat dan pemerintah daerah secara holistik. (3) Pemanfaatan teknologi informasi dan komunikasi secara optimal. (4) Peningkatan peranserta dunia usaha dan pengembangan industri telekomunikasi dan teknologi informasi. (5) Pengembangan sumber daya manusia di pemerintahan dan peningkatan e-literacy masyarakat. (6) Pelaksanaan pengembangan secara sistematis melalui tahapan yang realistis dan terukur.

Sampai saat ini, pemerintah desa khususnya Desa Tenjolayar dan Desa Tanjung Sari belum menerapkan sistem informasi manajemen desa dalam melayani berbagai kebutuhan masyarakat desa secara online contoh bidang administrasi kependudukan desa. Sistem pelayanan administrasi yang sedang berjalan masih mengunakan sistem manual tidak menggunakan e-goverment, sehingga Peneliti mentargetkan analisis dan perancangan egoverment dalam transparansi pemerintahan desa untuk : (1). meminimalisir resiko kesalahan Penelitian identitas, (2). lebih praktis dan cepat pada proses administrasi seperti pada pengajuan surat menyurut, (3). masyarakat desa dapat dilayani secara online 24 jam. Sistem yang sedang Peneliti analisis juga akan memiliki beberapa kelebihan diantaranya adalah dapat mengajukan surat pengantar KTP dan KK secara online dan dapat langsung diprint karena outputnya berupa file PDF, dan dapat dengan mudah mengajukan surat keterangan miskin karena sudah terfilter oleh sistem kemiskinan berdasarkan Keputusan Menteri Sosial dalam menentukan Indikator miskin (Keputusan Menteri Sosial Rebuplik Indonesia No. 146/HUK/2013), dan keperluan surat menyurat lainnya.

Hal ini yang mendorong Peneliti untuk menganalisis dan merancang e-goverment pada bidang sistem pelayanan adminsitrasi kependudukan yang berbasis web dan berbasis android di Pemerintahan Desa, sehingga masyarakat dapat mengakses kapanpun dan dimanapun, sehingga tujuan dari penelitian ini akan tercapai yaitu adalah mempermudah masyarakat desa dalam pelayanan administrasi desa yang prima dan mengayomi seluruh masyarakat desa tanpa terkecuali serta mendorong untuk meningkatkan kinerja Pemerintah Desa

Untuk memfokuskan pada masalah-masalah yang akan dibahas pada penelitian ini, maka diberikan batasan-batasan yaitu:

1. Registrasi dan Autentikasi.

Merupakan bagian utama dari sistem ini, dimana warga dapat memesan berbagai surat keterangan atau pengantar setelah melewati proses autentikasi dalam sistem. Adapun 12 jenis surat keterangan atau pengantar yang akan dilayani, yakni:

a. Surat Keterangan Lahir

b. Surat Keterangan Menikah

c. Surat Pengantar SKCK

d. Surat Keterangan

e. Surat Pengantar

f. Surat Keterangan Wali

g. Surat Keterangan Belum Pernah Menikah

h. Surat Keterangan Janda/Duda

i. Surat Keterangan Tidak Mampu

j. Permohonan KTP WNI

k. Permohonan KK Baru WNI

1. Surat Permohonan Akta Kelahiran

2. Pengolahan Pengajuan Surat Keterangan atau Pengantar.

Berisi program bagi masyarakat desa untuk memproses pengajuan masyarakat akan administrasi kependudukan, kemudian memberikan konfirmasi kepada warga tentang status pesanannya apakah ditunda, sedang diproses, atau sudah jadi.

3. Pengolahan Data Kependudukan.

Memungkinkan operator desa untuk mengolah data kependudukan yaitu meliputi tambah, edit dan hapus data penduduk (mutasi penduduk), serta pengelompokan data penduduk berdasarkan kategori tertentu (statistik penduduk).

4. Profil Desa dan Berita

Berisi profil desa secara lengkap untuk lebih memperkenalkan desa kepada masyarakat luas. Dan Selain untuk pelayanan administrasi kependudukan, sistem ini juga dapat untuk mengolah berbagai berita tentang desa, nasional, maupun internasional kemudian ditampilkan bagi masyarakat luas. 
Berdasarkan hasil observasi dan wawancara dari Pemerintah Desa Tenjolayar dan Tanjung Sari bahwa kedua Desa tersebut telah memiliki web site yang berdomain desa.id dan fungsi dari web site tersebut adalah untuk menyampaikan informasi kepada masyarakat Desa dan Pemerintah Kabupaten, maka Peneliti menganalisis visi dan misi kedua desa tersebut dengan menggunakan metode analisis SWOT yang terdiri dari analisis lingkungan internal (ALI) dan analisis lingkungan eksternal (ALE) dan menghasilkan perumusan asumsi melalui pembobotan analisis lingkungan internal (ALI) dan analisis lingkungan eksternal (ALE). Analisis SWOT juga menghasilkan analisis stratejik alternatif dan pilihan (ASAP) untuk mendapatkan analisis faktor penentu keberhasilan (FPK). Dari analisis diatas maka dapat disusun rencana penerapan e-goverment untuk tahun yang akan datang.

Penelitian ini menggunakan metode penelitian yang biasa dipergunakan dalam pengembangan sistem yaitu system development life cycle (SDLC). Tahapan utamanya dapat terdiri dari tahapan perencanaan sistem (systems planning), analisis sistem (systems analysis), desain sistem (system design), seleksi sistem (system selection), implementasi sistem (systems implementation) dan perawatan sistem (systems maintenance) (Jogiyanto, 2002). Adapun untuk metode pengumpulan datanya menggunakan metode observasi, wawancara, dan studi kepustakaan. Langkah terakhir pada proses pengembangan aplikasi ini adalah pengujian sistem. Sistem diuji menggunakan 2 cara, yaitu: Blackbox test dan Alpha test. Blackbox test, dilakukan oleh programmer sistem sedangkan Alpha test dilakukan bersamaan dengan pelatihan pengguna.

\section{Tinjauan Pustaka}

\subsection{Analisis Sistem}

Menurut Jogiyanto Hartono, analisis sistem (systems analysis) dapat didefinisikan sebagai penguraian dari suatu sistem informasi yang utuh ke dalam bagian-bagian komponennya dengan maksud untuk mengidentifikasikan dan mengevaluasi permasalahan-permasalahan, kesempatankesempatan, hambatan-hambatan yang terjadi dan kebutuhan-kebutuhan yang diharapkan sehingga dapat diusulkan perbaikan-perbaikannya, "Analisis dan Desain Sistem Informasi”.

Tahap analisis sistem dilakukan setelah tahap perencanaan sistem (systems planning) dan sebelum tahap desain sistem (systems design). Tahap analisis merupakan tahap yang kritis dan sangat penting, karena kesalahan di dalam tahap ini akan menyebabkan juga kesalahan di tahap selanjutnya. Di dalam tahap analisis, terdapat langkah-langkah dasar yang harus dilakukan oleh analisis sistem sebagai berikut:
1. Identify, yaitu mengidentifikasikan masalah.

2. Understand, yaitu memahami kerja sistem yang dibuat.

3. Analyze, yaitu menganalisis sistem.

4. Report, yaitu membuat laporan hasil analisis sistem.

\subsection{Analisis SWOT}

Dari Apriandes,. E (2013:20), analisis SWOT menurut Rangkuti (1997:18) “Analisis SWOT adalah identifikasi berbagai faktor secara sistematis untuk merumuskan strategi Perusahaan" Analisis SWOT mempunyai peranan penting dalam kemajuan usaha yang akhir-akhir ini semakin kompetitif persaingannya dalam mencapai tujuan. arti dari SWOT adalah Strengths, Weakness, Opportunity, and Threats. Yang artinya Kekuatan, Kelemahan, Peluang, dan Ancaman.

\subsection{E-Government}

Pada dasarnya, e-goverment adalah penggunaan teknologi informasi dan komunikasi (TIK) yang dapat meningkatkan hubungan antara pemerintah, masyarakat, dan bisnis, di dalamnya melibatkan otomatisasi dan komputerisasi pada prosedur paper-based yang mendorong cara baru dalam kepemimpinan, mendiskusikan dan menetapkan strategi, transaksi bisnis, mendengarkan warga dan komunitas, serta mengorganisasi dan menyampaikan informasi.

Luasnya peran TIK dalam proses bisnis membuat banyak instansi berlomba menerapkan TIK untuk proses terintegrasi, salah satunya adalah e-Goverment. Idealnya e-Goverment diharapkan dapat meningkatkan interaksi antara pemerintah, masyarakat, dan bisnis sehingga mendorong perkembangan politik dan ekonomi. Penerapan $e$ goverment di setiap instansi pemerintah Indonesia mengacu pada tahapan pengembangan e-goverment Nasional sesuai dengan kondisi setiap lembaga, yaitu :

1. Persiapan: pembuatan website di setiap lembaga, pendidikan SDM, penyediaan sarana akses publik, sosialisasi keberadaan layanan informasi elektronik (publik dan internal), pengembangan e-leadership dan awareness building, serta penyiapan peraturan.

2. Pematangan: pembuatan website layanan informasi publik interaktif dan hyperlink.

3. Pemantapan: penyediaan fitur transaksi elektronik, dan interoperabilitas antar lembaga.

4. Pemanfaatan: pembuatan layanan G2G, G2B, dan $\mathrm{G} 2 \mathrm{C}$ terintegrasi, pengembangan proses layanan e-goverment yang efektif dan efisien, dan penyempurnaan menuju kualitas best practice.

Isu permasalahan e-goverment ini dapat dibagi dalam 3 kategori yaitu manajemen, infrastruktur dan sumber daya manusia pelaksana. Secara umum yang dihadapi dalam sistem layanan e-goverment yang 
berkelanjutan dan terpadu (layanan level 3) adalah sebagai berikut:

1. Demografi penduduk dan pemerintahan yang tersebar dan kaya nilai konteks lokal (sosial. budaya, ekonomis) yang perlu ditonjolkan (isu konten lokal).

2. Beragamnya platfon, infrastruktur dan perangkat TIK tiap daerah (isu interoperasi dan sebaran letak perangkat/server, serta sistem monitoring dan sumber daya pelaksana).

3. Akses jaringan internet yang belum stabil (isu kehandalan infrastruktur dan layanan, dan dukungan sumber daya finansial).

Teknologi computing cloud dengan konsep penyediaan sumber daya komputasi sebagai layanan, telah dianggap sebagai paradigma baru dalam industri TIK saat ini. Dengan mendasarkan konsepnya pada bidang penelitian seperti SOA (servise Oriented Architecture), komputasi terdistribusi dan grid, serta virtualisasi, sumber daya TIK dapat dimamfaakan secara efisien untuk menghadirkan layanan dan aplikasi TIK terbarukan. Komputing cloud itu sendiri mempunyai benefit yang membuatnya berkembang menjadi pilihan bagi industri TIK masa depan.

Kesiapan menuju keberhasilan e-Government menurut Heeks (2001) berkaitan dengan:

1. Infrastruktur legal/hukum. Perlu adanya perangkat hukum untuk menangkal kejahatan digital, serta melindungi privasi, sekuriti data/informasi dan transaksi digital perorangan, perusahaan dan lembaga pemerintah.

2. Infrastruktur kelembagaan. Perlu adanya instansi khusus yang menangani $e$-Government yang memberikan layanan informasi kepada masyarakat termasuk layanan digital.

3. Infrastruktur SDM. Sistem kepegawaian perlu dapat dikembangkan agar mampu menarik SDM berkualitas professional dalam bidang telematika untuk ikut berkiprah dalam $e$ Government milik pemerintah.

4. Infrastruktur teknologi. Meskipun teknologi yang diperlukan relative mahal, tapi peluang kerjasama dengan swasta perlu dikembangkan dalam membangun infrastruktur teknologi untuk mendukung e-Government.

5. Suport, Capacity, Value;

6. Political environment, Leadership, Planning, Stakeholder, Transparency, Budgets, Technology, Innovation.

Informasi merupakan hasil data yang telah diolah menjadi bentuk yang lebih penting bagi pengguna dan lebih bermanfaat dalam mengambil keputusan. Sifat-sifat informasi adalah sebagai berikut :

1. Informasi harus berkualitas dan akurat bebas dari kesalahan karena sumber informasi yang sampai ke pengguna informasi kemungkinan besar banyak gangguan yang dapat merusak informasi.

2. Tepat pada waktunya, berarti sampai informasi harus tepat waktu tidak boleh terlambat sebab informasi yang usang tidak ada artinya lagi.

3. Informasi harus relevan sehingga informasi tersebut mempunyai nilai atau manfaat untuk penggunanya.

4. Informasi harus jelas, nilai informasi yang disajikan bisa dibaca dan dipahami dengan baik.

5. Informasi harus lengkap, yaitu nilai informasi yang disajikan kepada user tersedia dengan lengkap.

Berdasarkan acuan teori dan hasil penelitian yang dikemukakan oleh peneliti diatas dan oleh beberapa peneliti sebelumnya bahwa faktor keberhasilan dalam implementasi e-goverment adalah :

1. Peraturan, Peraturan merupakan dasar hukum bagi para pegawai pemerintah dalam rangka menjalankan tugas-tugas pemerintahan. Maka, perkara yang sangat penting untuk memayungi implementasi e-goverment dengan peraturan yang jelas dan sesuai dengan teknologi yang berkembang. J. Ramo' n Gil-Garc1'a dan Theresa A. Pardo (2005) menyebutkan bahwa terdapat dua hal terkait aspek legal dari sebuah e-goverment yaitu pertama mereka menyebut bahwa peraturan yang ketat yang dibuat sebelum atau atas ketidaktahuan atas teknologi yang relevan dengan e-goverment akan mempengaruhi keberhasilan proyek dan yang kedua bahwa mengembangkan kebijakan dan standar teknologi informasi pemerintah yang sesuai dapat memberikan kerangka yang memadai untuk inisiatif e-government untuk menjadi sukses.

2. Sistem penghargaan, Penghargaan dan sanksi (reward and punishment) lebih banyak terdapat di dalam artikel-artikel bidang manajemen. Gardner (2003) menyatakan bahwa untuk mengubah dan mempengaruhi prilaku seseorang, kita dapat menggunakan salah satu dari tiga pendekatan yaitu reasoning, reward atau punishment. Manajemen penghargaan (reward management) terkait dengan strategi, kebijakan dan proses yang dibutuhkan untuk memastikan kontribusi dari orang-orang dalam sebuah organisasi dengan sarana baik finansial maupun non finansial. Dalam konteks e-goverment, para pegawai akan lebih mau memberikan waktu dan tenaga pada sebuah proyek jika manajemen senior mengakui dan menghargai kontribusi mereka. Dengan kata lain, implementasi e-goverment membutuhkan keterlibatan para pegawai dan sistem imbalan memotivasi mereka untuk 
berpartisipasi dan menghasilkan pekerjaan dengan kualitas yang tinggi.

3. Sistem sanksi, Berkenaan dengan sanksi, walaupun kebijaksanaan yang konvensional menyatakan bahwa sanksi itu sebaiknya dihindari, namun pada hakikatnya sanksi tetap menjadi hal penting bagi pelaksanaan pekerjaan para pimpinan. Gardner menyatakan bahwa bagian dari manajemen sumber daya manusia yang efektif adalah memahami untuk menggunakan salah satu dari imbalan atau sanksi untuk merubah pegawai. Kebanyakan dari kita menggunakan salah satunya, namun sebenarnya kita benar-benar membutuhkan keduanya secara bersama-sama.

\subsection{Transparansi}

Menurut Piotrwosky dan Van Rizin (2007) dalam Dwiyanto (2011:241) menjelaskan bahwa transparansi dalam pemerintahan dapat didefinisikan sebagai kemampuan untuk menjelaskan apa yang terjadi didalam organisasi di sektor publik melalui pertemuan terbuka, pemberian akses terhadap dokumen, publikasi informasi melalui website secara aktif, perlindungan terhadap whistle blowers dan bahkan melalui pembocoran informasi secara ilegal.

Pada prinsipnya transparansi adalah bagian dari upaya pemerintah untuk menumbuhkan kepercayaan masyarakat terhadap pemerintah sekaligus melibatkan masyarakat dalam menjalankan fungsi controlling terhadap segala upaya atau usaha yang dilakukan oleh pemerintah dalam rangka meningkatkan kesejahteraan masyarakat.

Prinsip transparansi senantiasa akan dibarengi oleh prinsip keterbukaan informasi. Di Indonesia, keterbukaan informasi publik sejak tahun 2008 telah diatur ke dalam Undang-Undang No.14 Tahun 2008. Dalam pasal 1 undang undang ini disebutkan bahwa informasi adalah keterangan, penyataan, gagasan, dan tanda-tanda yang mengandung nilai, makna dan pesan baik data, fakta maupun penjelasannya yang disajikan dalam berbagai kemasan dan format sesuai dengan perkembangan teknologi informasi dan komunikasi secara elektronik maupun nonelektronik.

Sedang informasi publik adalah informasi yang dihasilkan, disimpan, dikelola, dikirim dan/atau diterima oleh penyelenggara negara dan penyelenggaraan negara dan/atau penyelenggara dan penyelenggaraan badan publik lainnya yang sesuai dengan undang-undang ini serta informasi lain yang berkaitan dengan kepentingan publik. Badan publik adalah lembaga eksekutif, legislatif dan yudikatif dan badan badan lain yang fungsi dan tugas pokoknya berkaitan dengan penyelenggaraan negara, yang sebagian atau seluruh dananya bersumber dari APBN dan/atau APBD, sumbangan masyarakat atau bantuan luar negeri.
SDLC (Systems Development Life Cycle), Siklus Hidup Pengembangan Sistem atau Systems Life Cycle (Siklus Hidup Sistem), dalam rekayasa sistem dan rekayasa perangkat lunak, adalah proses pembuatan dan pengubahan sistem serta model dan metodologi yang digunakan untuk mengembangkan sistem-sistem tersebut. Konsep ini umumnya merujuk pada sistem komputer atau informasi. SDLC juga merupakan pola yang diambil untuk mengembangkan sistem perangkat lunak, yang terdiri dari tahap-tahap: rencana (planning), analisis (analysis), desain (design), implementasi (implementation), uji coba (testing) dan pengelolaan (maintenance).

Dalam rekayasa perangkat lunak, konsep SDLC mendasari berbagai jenis metodologi pengembangan perangkat lunak. Metodologimetodologi ini membentuk suatu kerangka kerja untuk perencanaan dan pengendalian pembuatan sistem informasi, yaitu proses pengembangan perangkat lunak. Terdapat 3 jenis metode siklus hidup sistem yang paling banyak digunakan, yakni: siklus hidup sistem tradisional (traditional system life cycle), siklus hidup menggunakan prototyping (life cycle using prototyping), dan siklus hidup sistem orientasi objek (object-oriented system life cycle). SDLC juga merupakan metodologi umum dalam pengembangan sistem yang menandai kemajuan usaha analisis dan desain. Fase-fase yang terdapat didalam SDLC meliputi :

1. Perencanaan Sistem (Systems Planning)

2. Analisis Sistem (Systems Analysis)

3. Perancangan Sistem (Systems Design)

4. Implementasi Sistem (Systems Implementation)

5. Pemeliharaan Sistem (Systems Maintenance)

\section{Tujuan dan Manfaat Penelitian}

Adapun tujuan dari Penelitian pada skema Penelitian Dosen Pemula (PDP) adalah untuk meningkatkan kapasitas Dosen Pemula pada Penelitian Dasar dan untuk meningkatkan pelayanan administrasi secara online di Pemerintahan Desa berbasis e-goverment dan untuk meningkatkan kinerja perangkat desa.

Luaran yang akan dihasil pada penelitian PDP kali ini adalah:

1. Jurnal atau Prosiding tentang Analisis dan Perancangan e-goverment dalam transparansi Pemerintah Desa Tanjung Sari dan Desa Tenjolayar di Kabupaten Majalengka.

2. Membuat Perancangan sistem pelayanan prima berbasis e-goverment di Pemerintahan Desa.

Penelitian Dosen Pemula ini diharapkan dapat memberikan mamfaat bagi peneliti dan bagi Pemerintah Desa Tanjung Sari dan Desa Tenjolayar di Kabupaten Majalengka. Hasil Penelitian ini dapat digunakan sebagai dasar untuk penelitian lanjutan 
dalam pengembang sistem informasi pelayanan prima berbasis e-goverment, adapun mamafaat Penelitian ini adalah :

1. Bagi peneliti, penelitian ini diharapkan dapat meningkatkan Kapasitas sebagai Dosen Pemula dan menambah pengetahuan tentang Pelayanan Prima dan e-goverment.

2. Secara kelembagaan, penelitian ini diharapkan dapat dijadikan dasar untuk mengembangkan egoverment di Pemerintahan Desa Tanjung sari dan Tenjolayar di Kabupaten Majalengka.

\section{Hasil Luaran yang Dicapai}

\subsection{Hasil Analisis Swot}

1.Analisis Faktor Internal

Kekuatan ( Strengths)

1. Desa telah membangun infrastruktur Teknologi Informasi dan Komunikasi mulai tahun 2001 dengan membeli personal komputer, membangun Jaringan Intranet dan Internet, mengimplementasikan aplikasi seperti aplikasi Siladdu, Sedeka dan Siskeudes, Desa Tanjung sari dan desa Tenjolayar telah memiliki fasilitas Web Desa berdomain desa.id, Jaringan Internet baik VSAT maupun Jaringan Fiber Optik. Infrastruktur TIK ini digunakan untuk mendukung proses pelayanan di desa terhadap kebutuhan masyarakat desa.

2. Pemerintah Desa memiliki alokasi dana baik dari Dana Desa maupun dari Alolasi Dana Desa sebagai penunjang operasional di bidang Teknologi Informasi dan Komunikasi khususnya dalam hal Pelayanan kepada Masyarakat. (UU Desa pasal 4 huruf f dan pasal 7 ayat 3 huruf c).

3. Pemerintah Desa selalu mengadakan pelatihan-pelatihan dalam rangka peningkatan SDM baik ditingkat Kepada Desa dan Aparatur Pemerintah Desa sebagai pengguna/operator di bidang Teknologi Informasi dan Komunikasi baik yang diselenggarakan oleh Dinas Kabupaten atau Pemerintah Pusat. adapun pelatihan yang diselenggarakan bagi operator diantaranya adalah pelatihan aplikasi office, pelatihan penggunaan aplikasi di desa (seperti aaplikasi Siladdu, Sedeka dan Siskeudes).

4. Kepala Desa dan Para Aparatur Desa terbiasa menggunakan email, media sosial dan mengikuti grup/ komunitas di WhatsUp dalam berkomunikasi dan berkoordinasi tentnag desa, dan menambah pengetahuan karena terjadi proses knowledge sharing pada grup tersebut, dan dapat meningkatkan Kapasitas Kepala Desa dan Aparatur Pemerintah Desa.

5. Berdasarkan wawancara kepada masyarakat desa bahwa masyarakat desa sekarang sudah terbiasa menggunakan handphone berbasis android, untuk berbagai aktivitas kehidupannya baik untuk mendapatkan imformasi, bermain game, dan bertransaksi online (bayar Listrik, beli pulsa, bayar BPJS dan lain sebagainya.

6. Pemerintahan Desa sekarang cenderung dan sangat mendukung program untuk pengembangan TIK baik untuk mempermudah pelayanan publik sebagai mana yang diamanatkan oleh UU Desa. Sehingga ini bisa dijadikan kekuatan atau dasar masyarakat untuk mendorong pemerintah desa dalam mengimplementasikan salah saru yang diamanatkan dalam UU Desa.

Tabel 1. Indikator Kekuatan Internal Desa Urut Peringkat

\begin{tabular}{|c|c|}
\hline S1 & $\begin{array}{l}\text { Desa memiliki Inftrastruktur Teknologi } \\
\text { Informasi dan Komunikasi seperti Web } \\
\text { Desa berdomain desa.id, Jaringan Internet } \\
\text { baik VSAT maupun Jaringan Fibe Optik, } \\
\text { Personal Komputer dan Perangkat } \\
\text { Penunjang lainnya }\end{array}$ \\
\hline S2 & $\begin{array}{l}\text { Pemerintah Desa memiliki alokasi dana } \\
\text { sebagai penunjang operasional di bidang } \\
\text { Teknologi Informasi khususnya dalam hal } \\
\text { Pelayanan kepada Masyarakat. (UU Desa } \\
\text { pasal } 4 \text { huruf f dan pasal } 7 \text { ayat } 3 \text { huruf c) }\end{array}$ \\
\hline S3 & $\begin{array}{l}\text { Pemerintah Desa selalu mengadakan } \\
\text { pelatihan-pelatihan dalam rangka } \\
\text { peningkatan SDM baik ditingkat Kepada } \\
\text { Desa dan Aparatur Pemerintah Desa sebagai } \\
\text { pengguna di bidang Teknologi Imformasi } \\
\text { dan Komunikasi baik yang diselenggarakan } \\
\text { oleh Dinas Kabupaten atau Pemerintah } \\
\text { Pusat. }\end{array}$ \\
\hline S4 & $\begin{array}{l}\text { Kepala Desa dan Para Aparatur Desa } \\
\text { terbiasa menggunakan email, Media Sosial } \\
\text { dan mengikuti grup/ komunitas di WhatsUp } \\
\text { dalam menambah pengetahuan atau pada } \\
\text { proses knowledge sharing untuk } \\
\text { meningkatkan Kapasitas Kepala Desa dan } \\
\text { Aparatur Pemerintah Desa. }\end{array}$ \\
\hline S5 & $\begin{array}{l}\text { Masyarakat Desa terbiasa menggunakan } \\
\text { handphone berbasis android untuk } \\
\text { mendapatkan imformasi. }\end{array}$ \\
\hline S6 & 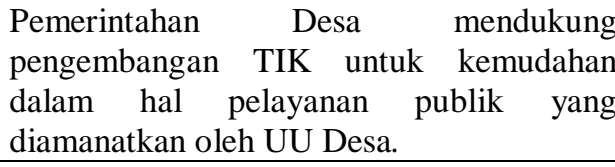 \\
\hline
\end{tabular}

2. Kelemahan ((Weaknesses)

1. Pemerintah Kabupaten selalu mengkitisi kepada pemerintah desa bahwa belum melihat dampak bottom line dari Investasi TIK dalam hal pembangunan pelayanan publik secara online sehingga pemerintah desa harus berkomitmen dengan RPJM Desanya baik dalam hal pelayanan desa berbasis TIK dan egovermet maupuan hal lainnya.

2. Perubahan jaman yang sangat pesat dan cepat membutuhkan peranan Kepala Desa dalam membangun kesadaran baik masyarakat 
maupun aparatur desa dalam menerima budaya baru dalam hal pelayanan publik berbasis TIK dan e-goverment, dan harus mensosialisasikan program ini kepada Masyarakat agar muncul kesadaran dari Masyarakat, sehingga tujaun dari pelayanan prima di desa dapat tercapai.

3. Ganti Kepala Desa dan jajarannya sangat memungkinkan terjadinya loss knowledge atau hilangnya pengetahuan kepala desa dan aparatur desa yang disebabkan terjadinya mutasi/pergantian aparatur pemerintah desa sangat merugikan keberlansungan roda pemerintahan desa. Karena knowledge di Pemerintah Desa masih didominasi oleh tacit knowledge.

4. Pemerintah Desa harus berkomitmen untuk mengontrol penggunaan akses internet di desa dan dipastikan hanya digunakan untuk penunjang palayanan prima di desa dan kegiatan positif lainnya dalam rangka menambah pengetahuan para aparatur desa, sehingga tenaga ahli dibidang TIK sangat dibutuhkan untuk kelansungan pelaksanaan $e$ goverment.

5. Prosentasi Masyarakat Desa yang berpengetahuan TIK masih rendah dan kurang memahami mamfaat TIK untuk membantu kemudahan dalam segala aspek kehidupan baik dalam hal Pelayanan publik, bertransaksi ataupun untuk sekedar mencari informasi, tujuan dari pelayanan berbasis e-goverment ini adalah salah satunya untuk meningkatkan taraf hidup atau kesejahteraan masyarakat desa.

6. Masih banyak masyarakat desa yang tidak mengerti lebih dalam tentang Implementasi UU Desa untuk meningkatkan kesejahteraan masyarakatnya. Diperlukan lagi sosialisasi Implementasi UU Desa kepada masyarakat desa agar masyarakat desa merasakan keuntungan dengan adanya UU Desa, tidak hanya segelintir masyarakat saja.

Tabel 2. Indikator Kelemahan Internal Desa Urut Peringkat

\begin{tabular}{|l|l|}
\hline W1 & $\begin{array}{l}\text { Pemerintah Desa belum melihat dampak } \\
\text { bottom line dari Investasi TIK dalam hal } \\
\text { pembangunan pelayanan publik secara } \\
\text { online. }\end{array}$ \\
\hline W2 & $\begin{array}{l}\text { Perlu peranan Kepala Desa dalam } \\
\text { membangun kesadaran baik masyarakat } \\
\text { maupun aparatur desa dalam menerima } \\
\text { budaya baru dalam hal pelayanan publik } \\
\text { berbasis TIK. }\end{array}$ \\
\hline W3 & $\begin{array}{l}\text { Kemungkinan loss knowledge atau } \\
\text { hilangnya pengetahuan Aparatur Desa } \\
\text { disebabkan terjadinya mutasi/pergantian } \\
\text { aparatur pemerintah desa. Knowledge di } \\
\text { Pemerintah Desa masih didominasi oleh } \\
\text { tacit knowledge. }\end{array}$ \\
\hline
\end{tabular}

\begin{tabular}{|l|l|}
\hline W4 & $\begin{array}{l}\text { Pemerintah Desa kurang mengontrol } \\
\text { penggunaan akses internet untuk } \\
\text { penunjang palayanan dan kegiatan positif } \\
\text { lainnya. }\end{array}$ \\
\hline W5 & $\begin{array}{l}\text { Prosentasi Masyarakat Desa yang } \\
\text { berpengetahuan TIK masih rendah dan } \\
\text { kurang memahami mamfaat TIK untuk } \\
\text { membantu kemudahan dalam hal } \\
\text { Pelayanan publik untuk meningkatkan } \\
\text { kesejahteraan masyarakat Desa. }\end{array}$ \\
\hline W6 & $\begin{array}{l}\text { Masih banyak masyarakat desa yang tidak } \\
\text { mengerti lebih dalam tentang Implementasi } \\
\text { UU Desa untuk meningkatkan } \\
\text { kesejahteraan masyarakatnya. }\end{array}$ \\
\hline
\end{tabular}

3. Analisis Faktor Eksternal

A. Kesempatan (Opportunities)

1. Pemerintah Desa harus fokus dan berkomitmen mengembangkan e-goverment karena memiliki peluang sangat besar apabila dilihat dari dana untuk operasional mengembangkan e-goverment tersedia ( dapat dialokasikan atau dianggarkan di RPJM Desanya masing masing) dan harapan masyarakat adalah dapat meningkat pelayanan yang optimal dan dapat meningkatkan kesejahteraan masyarakt desa.

2. Ketetapan dan Payung hukum untuk mengembangkan e-goverment sudah cukup banyak dan sudah disosialisasikan, apa lagi dalam hal pelayanan kepada masyarakat desa sudah tersirat pada UU Desa No. 6 Tahun 2014. Sehingga peluang desa menjadikan sistem pelayanan prima bisa terlaksana.

3. Pada era revlusi industri 4.0 masyarakat desa yang memiliki perankat telekomunikasi canggih sudah banyak dan Prosentasi masyarakat Desa yang memilik handphone berbasis android berdasarkan wawancara lumayan banyak khususnya di desa tenjolayar dan tanjungsari.

4. Untuk mengembankan potensi desa baik pada sumber daya manusia maupun sumber daya alam maka pemerintah pusat selalu memberikan bantuan baik dana maupun berupa pelatihan, salah satu tujuannya untuk meningkatkan pelayanan di Pemerintah Desa yang tersirat pada UU Desa Nomer 14 tahun 2004.

5. Kebutuhan akan informasi dan transaksi online baik untuk masyarakat Desa maupun untuk aparatur pemerintah Desa akan terus meningkat sejalan dengan perkembangan dunia Teknologi Informasi dan Komunikasi. Layanan yang berbasis TIK akan mendominasi atau mewarnai kehidupan masyarakt desa karena akan memberikan kehidupan yang nyaman baik hal pelayanan administrasi maupun bertransaksi.

6. Salah saru unsur untuk meningkatkan kesejahteraan masyarakat Desa adalah 
Pemerintah Desa segera mengimplementasikan e-goverment dalam hal pelayanan publik baik untuk pelayanan administrasi maupun untuk palayanan lainnya.

Tabel 3. Indikator Kesempatan Eksternal Desa Urut Peringkat

\begin{tabular}{|c|c|}
\hline O1 & $\begin{array}{l}\text { Pemerintah Desa harus fokus dan } \\
\text { berkomitmen mengembangkan e- } \\
\text { goverment untuk peningkatan palayanan } \\
\text { yang optimal dalam mensejahterakan } \\
\text { masyarakt desa. }\end{array}$ \\
\hline $\mathrm{O} 2$ & $\begin{array}{l}\text { Payung hukum untuk mengembangkan } e \text { - } \\
\text { goverment sudah cukup, apa lagi dalam hal } \\
\text { pelayanan kepada masyarakat desa tersirat } \\
\text { pada UU Desa No. } 6 \text { Tahun } 2014 \text {. }\end{array}$ \\
\hline $\mathrm{O} 3$ & $\begin{array}{l}\text { Prosentasi masyarakat Desa yang memilik } \\
\text { handphone berbasis android banyak. }\end{array}$ \\
\hline $\mathrm{O} 4$ & $\begin{array}{l}\text { Pemerintah Desa selalu mendapatkan } \\
\text { bantuan baik dana maupun berupa pelatihan } \\
\text { dari Pemerintah Pusat untuk meningkatkan } \\
\text { pelayanan di Pemerintah Desa. }\end{array}$ \\
\hline O5 & $\begin{array}{l}\text { Kebutuhan akan informasi dan transaksi } \\
\text { online baik untuk masyarakat Desa maupun } \\
\text { untuk pemerintah Desa akan terus } \\
\text { meningkat. }\end{array}$ \\
\hline O6 & $\begin{array}{l}\text { Untuk meningkatkan Kesejahteraan } \\
\text { masyarakat Desa maka Pemerintah Desa } \\
\text { segera mengimplementasikan e-goverment } \\
\text { dalam hal pelayanan publiknya. }\end{array}$ \\
\hline
\end{tabular}

\section{B. Tantangan (Threats)}

1. Untuk membangun sistem pelayanan yang prima dan apalagi berbasis e-goverment maka tenaga ahli yang profesional harus dipersiapkan oleh desa guna keberlangsungan aplikasi berbasis e-goverment .

2. Perkembangan Teknologi Imformasi dan Komunikasi dalam hal palayanan berbasis $e$ govermet di Indonesia sangat cepat sehingga memerlukan komitment Kepala Desa dan masyarakat desa dalam pembuatan RPJM Desa.

3. Akses untuk mendapatkan informasi semakin mudah karena tersedia infrastuktur Teknologi Informasi dan Komunikasi, di khawatirkan terjadi kejahatan di dunia internet berupa mendapatkan serangan ke web e-goverment sehingga SDM aparatur desa harus dipersiapkan dengan cara sharing knowledge.

4. Semakin bertambahnya pengetahuan dibidang Teknologi Informasi dan Komunikasi, atau bertambahnya tacit knowledge pada aparatur desa tersebut dikhawatirkan tidak berkomitment untuk sharing knowledge dan dalam membangun e-goverment tanpa penghargaan dari pemerintah Desa. Harus ada apresiasi dari pemerintah desa baik berupa tambahan honor atau voucher belanja di bumdes.

5. Dikhawatirkan para aparatur desa dan masyarakat terlena kenyamanan pelayanan berbasis TIK sehingga akan mengurangi kebersampan atau memiliki sifat individualisme dan hilangnya budaya gotong royong/kebersamaan di masyarakat desa.

6. Belum memiliki Sumber Daya Manusia pada pemerintah desa tenjolayar dan tanjungsari khususnya dalam bidang Teknologi Informasi dan Komunikasi merupakan tantangan pemerintah desa untuk membangun SDM yang ahli dibidang TIK untuk menjaga kestabilan dan berkelanjutan apliasi berbasis $e$ goverment.

Tabel 4. Indikator Tantangan Eksternal Desa Urut Peringkat

\begin{tabular}{|c|c|}
\hline $\mathrm{T} 1$ & $\begin{array}{l}\text { Tidak memiliki tenaga ahli yang profesional } \\
\text { guna keberlangsungan } e \text {-goverment. }\end{array}$ \\
\hline $\mathrm{T} 2$ & $\begin{array}{l}\text { Perkembangan Teknologi Imformasi dan } \\
\text { Komunikasi dalam hal palayanan berbasis } \\
\text { e-govermet di Indonesia sangat cepat } \\
\text { sehingga memerlukan komitment Kepala } \\
\text { Desa dan masyarakat desa dalam } \\
\text { menjalankan Undang-Undang Desa. }\end{array}$ \\
\hline T3 & $\begin{array}{l}\text { Akses untuk mendapatkan informasi } \\
\text { semakin mudah karena tersedia infrastuktur } \\
\text { Teknologi Informasi dan Komunikasi, di } \\
\text { khawatirkan terjadi kejahatan di dunia } \\
\text { internet dan membuka web berbau } \\
\text { pornografi. }\end{array}$ \\
\hline $\mathrm{T} 4$ & $\begin{array}{l}\text { Semakin bertambahnya pengetahuan } \\
\text { dibidang Teknologi Informasi dan } \\
\text { Komunikasi, mengkhawatirkan aparatur } \\
\text { desa tidak berkomitment dalam } \\
\text { membangun } \quad \text { e-goverment } \\
\text { penghargaan dari pemerintah Desa. }\end{array}$ \\
\hline T5 & $\begin{array}{l}\text { Dikhawatirkan para aparatur desa dan } \\
\text { masyarakat terlena kenyamanan pelayanan } \\
\text { berbasis TIK sehingga akan mengurangi } \\
\text { kebersamaan. Hilangnya budaya gotong } \\
\text { royong/kebersamaan di masyarakat desa. }\end{array}$ \\
\hline $\mathrm{T}$ & $\begin{array}{l}\text { Belum memiliki SDM pemerintah desa } \\
\text { dalam bidang TIK. }\end{array}$ \\
\hline
\end{tabular}

\section{Matriks IFE dan EFE}

Pengolahan data dari swot diatas dimasukkan ke Matriks IFE dan EFE ini, akan dilakukan perhitungan dengan memberikan bobot, serta penentuan rating dari dampak yang akan dihasilkan dari potensi yang dimiliki oleh perusahaan. Perusahaan akan memiliki posisi internal yang kuat dan respon yang baik terhadap peluang dan ancaman apabila memiliki nilai berada di atas rata-rata yakni 2.5 . 
Total Bobot :

Lingkungan Internal $($ IFE) $=100 \%$

Lingkungan Eksternal $(\mathrm{EFE})=100 \%$

Penentuan Rating :

Untuk Matriks IFE:

$1=$ Kelemahan besar

3 = Kekuatan kecil

$2=$ Kelemahan kecil
$4=$ Kekuatan besar

Untuk Matriks EFE:

$1=$ Respon jelek

$3=$ Respon di atas rata-rata

$2=$ Respon rata-rata

$4=$ Respon luar biasa

Matriks IFE (Internal Factor Evalution)

Tabel 5. Matrik IFE

\begin{tabular}{|c|c|c|c|c|}
\hline No & KEKUATAN & Bobot & Rating & Jumlah \\
\hline $\mathrm{S} 1$ & $\begin{array}{l}\text { Desa memiliki Inftrastruktur Teknologi Informasi dan Komunikasi seperti } \\
\text { Web Desa berdomain desa.id, Jaringan Internet baik VSAT maupun } \\
\text { Jaringan Fibe Optik, Personal Komputer dan Perangkat Penunjang } \\
\text { lainnya }\end{array}$ & 0.074 & 3 & 0.222 \\
\hline $\mathrm{S} 2$ & $\begin{array}{l}\text { Pemerintah Desa memiliki alokasi dana sebagai penunjang operasional di } \\
\text { bidang Teknologi Informasi khususnya dalam hal Pelayanan kepada } \\
\text { Masyarakat. (UU Desa pasal } 4 \text { huruf f dan pasal } 7 \text { ayat } 3 \text { huruf c) }\end{array}$ & 0.086 & 3 & 0.258 \\
\hline S3 & $\begin{array}{l}\text { Pemerintah Desa selalu mengadakan pelatihan-pelatihan dalam rangka } \\
\text { peningkatan SDM baik ditingkat Kepada Desa dan Aparatur Pemerintah } \\
\text { Desa sebagai pengguna di bidang Teknologi Imformasi dan Komunikasi } \\
\text { baik yang diselenggarakan oleh Dinas Kabupaten atau Pemerintah Pusat. }\end{array}$ & 0.86 & 4 & 0.344 \\
\hline S4 & $\begin{array}{l}\text { Kepala Desa dan Para Aparatur Desa terbiasa menggunakan email, Media } \\
\text { Sosial dan mengikuti grup/ komunitas di WhatsUp dalam menambah } \\
\text { pengetahuan atau pada proses knowledge sharing untuk meningkatkan } \\
\text { Kapasitas Kepala Desa dan Aparatur Pemerintah Desa. }\end{array}$ & 0.09 & 3 & 0.27 \\
\hline S5 & $\begin{array}{l}\text { Masyarakat Desa terbiasa menggunakan handphone berbasis android } \\
\text { untuk mendapatkan imformasi. }\end{array}$ & 0.094 & 1 & 0.094 \\
\hline S6 & $\begin{array}{l}\text { Pemerintahan Desa mendukung pengembangan TIK untuk kemudahan } \\
\text { dalam hal pelayanan publik yang diamanatkan oleh UU Desa. }\end{array}$ & 0.09 & 2 & 0.18 \\
\hline & \multicolumn{3}{|l|}{ SUBTOTAL } & 1.368 \\
\hline No & KELEMAHAN & Bobot & Rating & Jumlah \\
\hline W1 & $\begin{array}{l}\text { Pemerintah Desa belum melihat dampak bottom line dari Investasi TIK } \\
\text { dalam hal pembangunan pelayanan publik secara online. }\end{array}$ & 0.086 & 4 & 0.344 \\
\hline W2 & $\begin{array}{l}\text { Perlu peranan Kepala Desa dalam membangun kesadaran baik } \\
\text { masyarakat maupun aparatur desa dalam menerima budaya baru dalam } \\
\text { hal pelayanan publik berbasis TIK. }\end{array}$ & 0.062 & 3 & 0.186 \\
\hline W3 & $\begin{array}{l}\text { Kemungkinan loss knowledge atau hilangnya pengetahuan Aparatur Desa } \\
\text { disebabkan terjadinya mutasi/pergantian aparatur pemerintah desa. } \\
\text { Knowledge di Pemerintah Desa masih didominasi oleh tacit knowledge. }\end{array}$ & 0.073 & 2 & 0.146 \\
\hline W4 & $\begin{array}{l}\text { Pemerintah Desa kurang mengontrol penggunaan akses internet untuk } \\
\text { penunjang palayanan dan kegiatan positif lainnya. }\end{array}$ & 0.086 & 3 & 0.258 \\
\hline W5 & $\begin{array}{l}\text { Prosentasi Masyarakat Desa yang berpengetahuan TIK masih rendah dan } \\
\text { kurang memahami mamfaat TIK untuk membantu kemudahan dalam hal } \\
\text { Pelayanan publik untuk meningkatkan kesejahteraan masyarakat Desa. }\end{array}$ & 0.086 & 2 & 0.172 \\
\hline W6 & $\begin{array}{l}\text { Masih banyak masyarakat desa yang tidak mengerti lebih dalam tentang } \\
\text { Implementasi UU Desa untuk meningkatkan kesejahteraan } \\
\text { masyarakatnya. }\end{array}$ & 0.09 & 2 & 0.18 \\
\hline & \multicolumn{3}{|l|}{ SUBTOTAL } & 1.286 \\
\hline & \multicolumn{3}{|l|}{ TOTAL } & 2.654 \\
\hline
\end{tabular}


Matriks EFE (External Factor Evalution)

\begin{tabular}{|c|c|c|c|c|}
\hline No & PELUANG & Bobot & Rating & Jumlah \\
\hline $\mathrm{O} 1$ & $\begin{array}{l}\text { Pemerintah Desa harus fokus dan berkomitmen mengembangkan } e \text { - } \\
\text { goverment untuk peningkatan palayanan yang optimal dalam } \\
\text { mensejahterakan masyarakt desa. }\end{array}$ & 0.083 & 2 & 0.166 \\
\hline $\mathrm{O} 2$ & $\begin{array}{l}\text { Payung hukum untuk mengembangkan e-goverment sudah cukup, apa } \\
\text { lagi dalam hal pelayanan kepada masyarakat desa tersirat pada UU } \\
\text { Desa No. } 6 \text { Tahun } 2014 \text {. }\end{array}$ & 0.09 & 4 & 0.384 \\
\hline $\mathrm{O} 3$ & $\begin{array}{l}\text { Prosentasi masyarakat Desa yang memilik handphone berbasis } \\
\text { android banyak. }\end{array}$ & 0.083 & 4 & 0.332 \\
\hline $\mathrm{O} 4$ & $\begin{array}{l}\text { Pemerintah Desa selalu mendapatkan bantuan baik dana maupun } \\
\text { berupa pelatihan dari Pemerintah Pusat untuk meningkatkan } \\
\text { pelayanan di Pemerintah Desa. }\end{array}$ & 0.079 & 2 & 0.158 \\
\hline O5 & $\begin{array}{l}\text { Kebutuhan akan informasi dan transaksi online baik untuk masyarakat } \\
\text { Desa maupun untuk pemerintah Desa akan terus meningkat. }\end{array}$ & 0.104 & 2 & 0.208 \\
\hline O6 & $\begin{array}{l}\text { Untuk meningkatkan Kesejahteraan masyarakat Desa maka } \\
\text { Pemerintah Desa segera mengimplementasikan e-goverment dalam } \\
\text { hal pelayanan publiknya. }\end{array}$ & 0.061 & 2 & 0.122 \\
\hline & \multicolumn{3}{|l|}{ SUBTOTAL } & 1.37 \\
\hline No & ANCAMAN & Bobot & Rating & Jumlah \\
\hline $\mathrm{T} 1$ & $\begin{array}{l}\text { Tidak memiliki tenaga ahli yang profesional guna keberlangsungan } e \text { - } \\
\text { goverment. }\end{array}$ & 0.104 & 4 & 0.416 \\
\hline $\mathrm{T} 2$ & $\begin{array}{l}\text { Perkembangan Teknologi Imformasi dan Komunikasi dalam hal } \\
\text { palayanan berbasis e-govermet di Indonesia sangat cepat sehingga } \\
\text { memerlukan komitment Kepala Desa dan masyarakat desa dalam } \\
\text { menjalankan Undang-Undang Desa. }\end{array}$ & 0.065 & 1 & 0.065 \\
\hline T3 & $\begin{array}{l}\text { Akses untuk mendapatkan informasi semakin mudah karena tersedia } \\
\text { infrastuktur Teknologi Informasi dan Komunikasi, di khawatirkan } \\
\text { terjadi kejahatan di dunia internet dan membuka web berbau } \\
\text { pornografi. }\end{array}$ & 0.061 & 2 & 0.122 \\
\hline $\mathrm{T} 4$ & $\begin{array}{l}\text { Semakin bertambahnya pengetahuan dibidang Teknologi Informasi } \\
\text { dan Komunikasi, mengkhawatirkan aparatur desa tidak berkomitment } \\
\text { dalam membangun e-goverment tanpa penghargaan dari pemerintah } \\
\text { Desa. }\end{array}$ & 0.1 & 2 & 0.2 \\
\hline T5 & $\begin{array}{l}\text { Dikhawatirkan para aparatur desa dan masyarakat terlena kenyamanan } \\
\text { pelayanan berbasis TIK sehingga akan mengurangi kebersamaan. } \\
\text { Hilangnya budaya gotong royong/kebersamaan di masyarakat desa. }\end{array}$ & 0.079 & 3 & 0.237 \\
\hline T6 & $\begin{array}{l}\text { Kekurangan SDM Pemerintah Desa dalam bidang TIK dan e- } \\
\text { goverment. }\end{array}$ & 0.087 & 3 & 0.261 \\
\hline & \multicolumn{3}{|l|}{ SUBTOTAL } & 1.301 \\
\hline & \multicolumn{3}{|l|}{ TOTAL } & 2.671 \\
\hline
\end{tabular}




\subsection{Digaram Konteks}

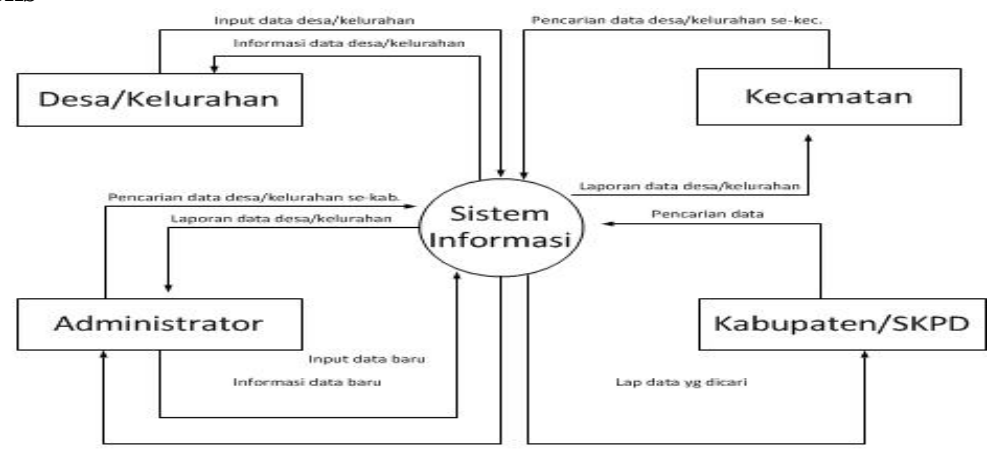

Gambar 1. Diagram Konteks

\subsection{Data Flow Diagram Level O (DFD)}

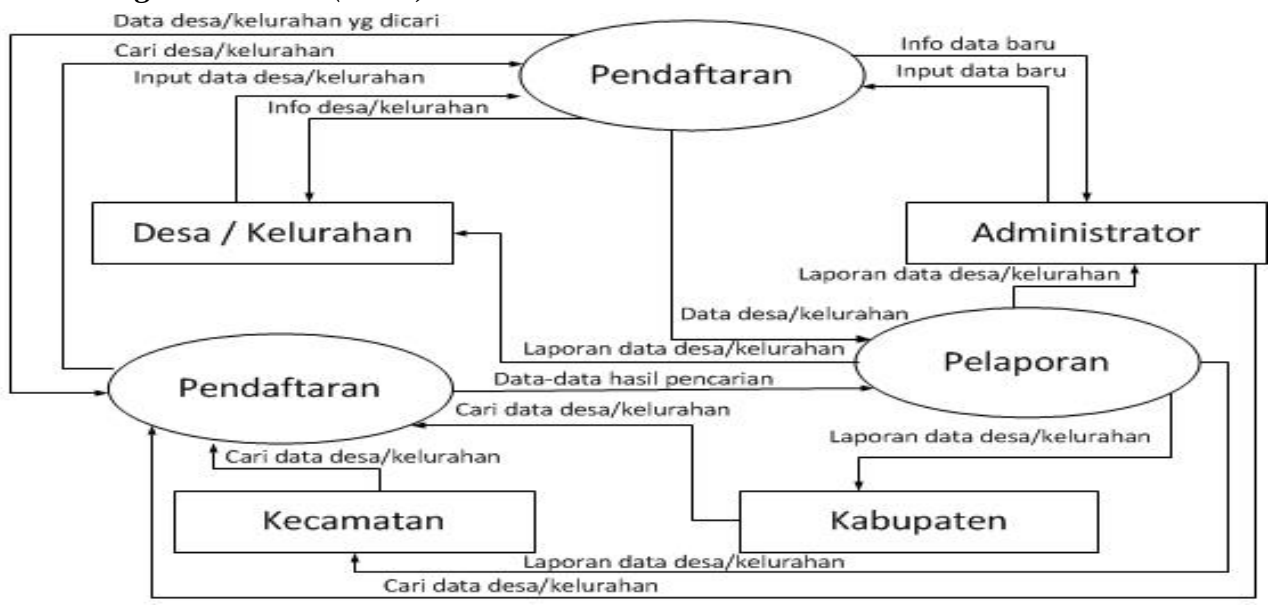

Gambar 2. Data Flow Diagram

\subsection{Data Flow Diagram Level 1}

Proses Pendataan

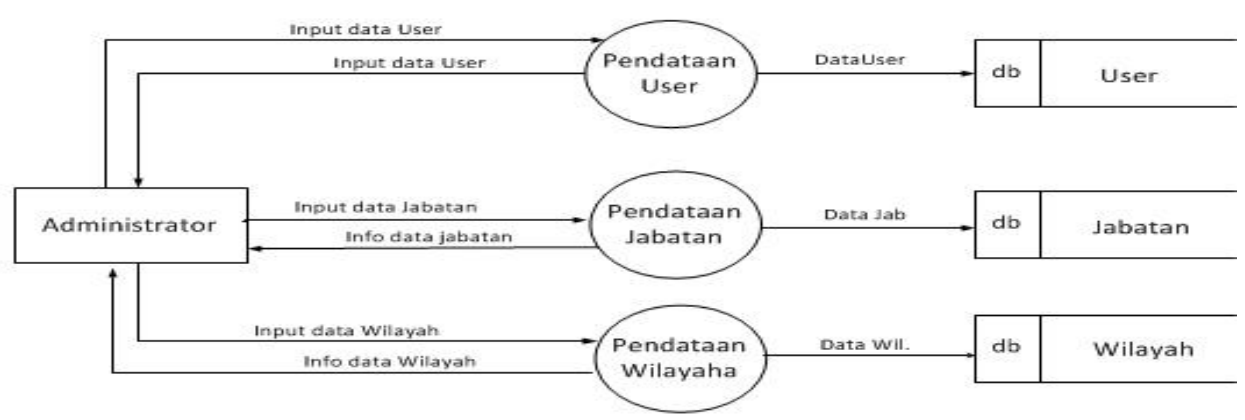

Gambar 3. Data Flow Diagram Level 1 Pendataan User 
4.5 Data Flow Diagram Level 1

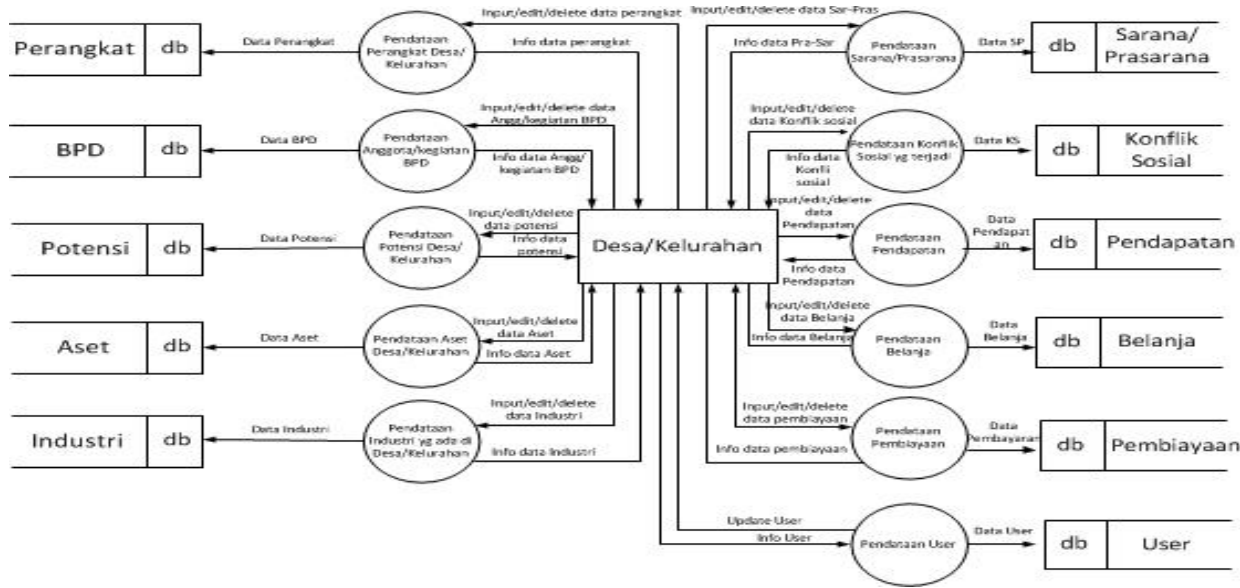

Gambar 4. Data Flow Diagram Level 1 Pelayanan Desa

\subsection{Data Flow Diagram Level 1 Proses Pencarian}

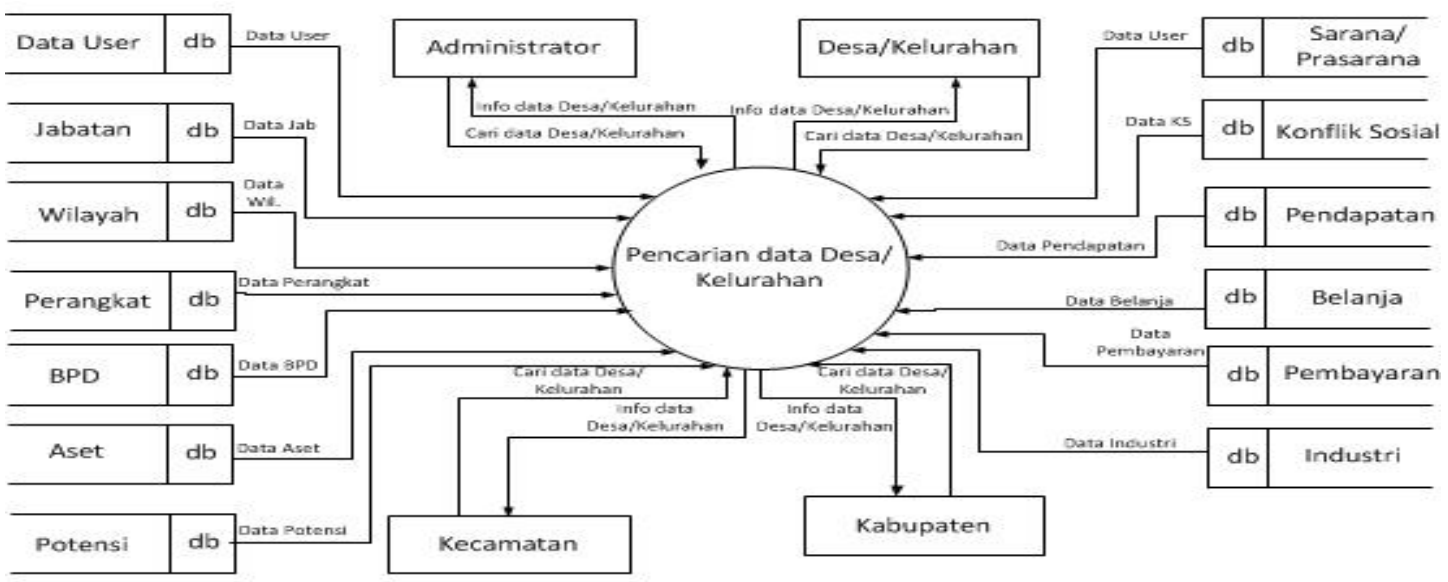

Gambar 5. Data Flow Diagram Level 1 Proses Pencarian

\subsection{Data Flow Diagram Level 1 Proses Pelaporan}

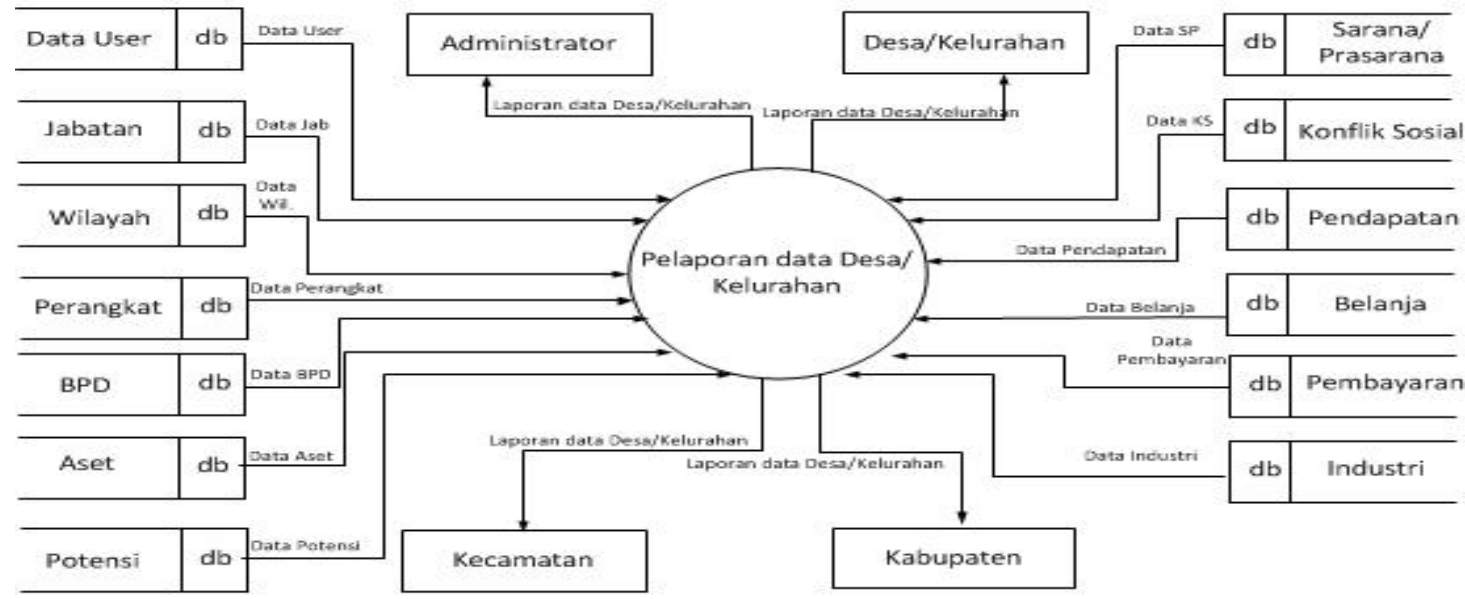

Gambar 6. Data Flow Diagram Level 1 Proses Pelaporan 


\subsection{Perancangan Database}

Entity Relation Diagram

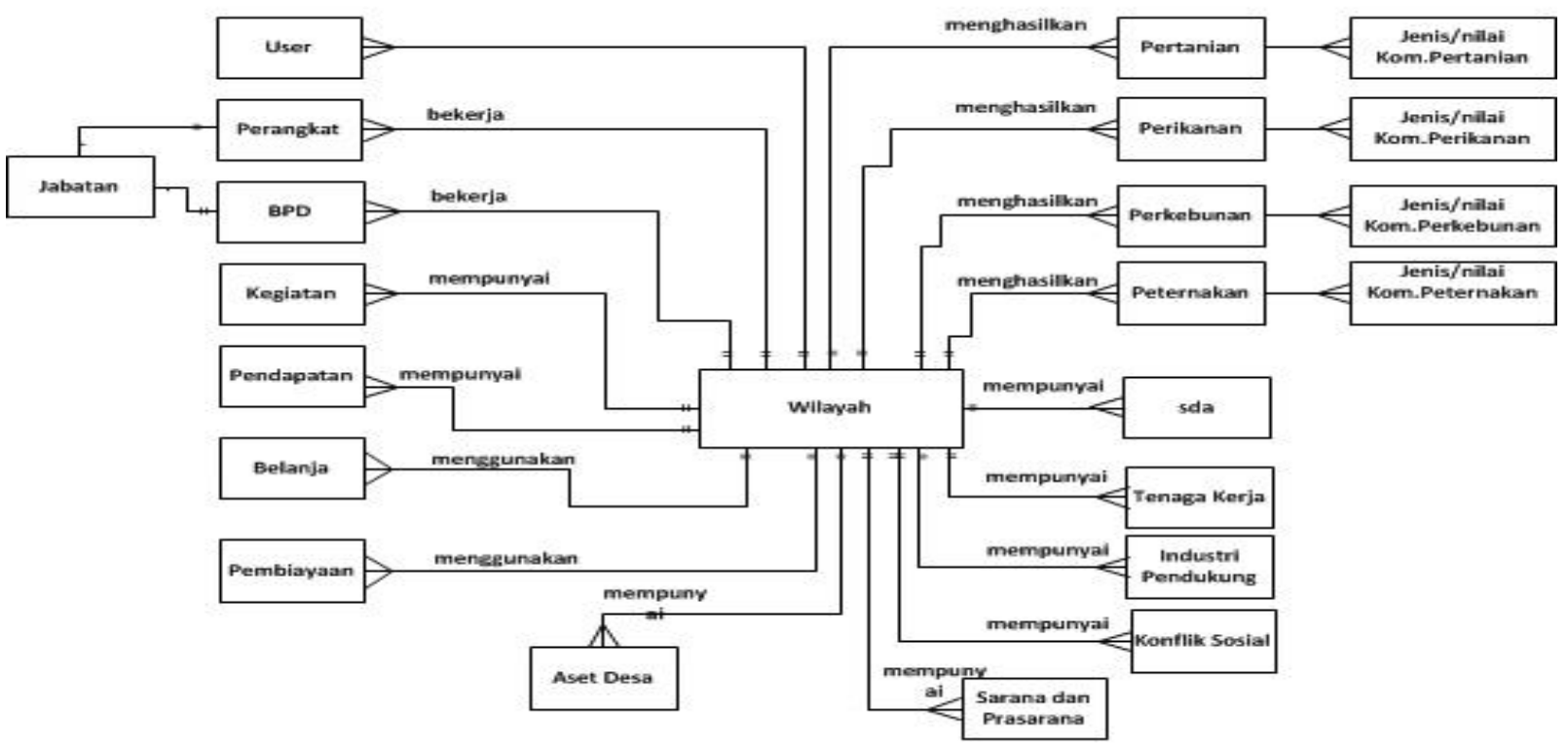

Gambar 7. Entity Relational Digaram (ERD)

\section{Kesimpulan dan Saran}

\subsection{Kesimpulan}

Dari hasil analisis dan perancangan $e$ goverment dalam transparansi sistem pemerintahan Desa, Penulis dapat menyimpulkan bahwa Perancangan Pelayanan di desa berbasis $e$ goverment dapat diterapkan dengan berbagai persyaratan baik Sumber Daya Manusia maupun peralatan pendukung dibidang TIK untuk terlaksananya Pelayanan Desa yang prima. Penulis juga sudah membuat rancangan aplikasi pelayanan berbasis e-goverment berbasarkan analisis penulis terhadap 2 desa yaitu desa tanjungsari dan desa tenjolayar.

\subsection{Saran}

Perancangan Aplikasi Electronic Government yang akan diterapkan di desa tenjolayar dan tanjung sari akan di Implementasikan setelah tahap metode benckmarking dengan sistem pelayanan terkini di Indonesia, baik melalui kajian literasi maupun observasi ke tempat lain yang sudah menjalankan sistem pelayanan semodel ini, dan ini merupakan saran penulis agar dilakukan metode benckmarking.

\section{REFERENSI}

[1]. Apriandes, E,. (2013) Analisis SWOT Guna Penyusunan Rencana Induk E-Government Pada Pemerintahan Daerah Kabupaten Muara
Enim, Sripsi, Program Studi Teknik Informatika Fakultas Ilmu Komputer Universitas Bina Darma.

[2]. Daeng Sudirwo, 1981, Pokok-Pokok Pemerintahan Di Daerah dan Pemerintahan Desa, Angkasa, Bandung, h. 41

[3]. Peraturan Menteri Dalam Negeri Nomor 35 Tahun 2007 Tentang Pedoman Umum Tata Cara Pelaporan Dan Pertanggungjawaban Penyelenggaraan Pemerintahan Desa.

[4]. Putu Krishna Yogiswara, Piers Andreas Noak, I Ketut Winaya,. Peranan E-Government Dalam Mendukung Transparansi Dan Keterbukaan Informasi Publik (Studi Kasus Website Resmi Pemerintah Kabupaten Klungkung), Program Studi Administrasi Negara Fakultas Ilmu Sosial dan Ilmu Politik Universitas Udayana.

[5]. Susilowati, E, B dan Purnama, B, E. 2011. Analisis Dan Perancangan Sistem Informasi Pasien Rumah Sakit Umum Nirmala Suri Sukoharjo. Journal Speed - Sentra Penelitian Engineering dan Edukasi - Volume 3 No 4 1017.

[6]. Undang-Undang Nomor 6 Tahun 2014 tentang Desa (Lembaran Negara Republik Indonesia Tahun 2014 Nomor 7, Tambahan Lembaran Negara Republik Indonesia Nomor 5495)

[7]. ….....2005.(http://www.transparansi.or.id/good _governance/prinsi p.html) 2005 desa yang bergerak dibidang tranparansi. 